\title{
Dabbing Applicator Device
}

National Cancer Institute

\section{Source}

National Cancer Institute. Dabbing Applicator Device. NCI Thesaurus. Code C149424.

Closure with dabbing device. 